\title{
Chronic Illnesses and Injuries: An Evaluation of their Impact on Occupation and Revenues ${ }^{1}$
}

\author{
Emmanuel Duguet ${ }^{2}$ and Christine le Clainche ${ }^{3}$
}

January 2012

\begin{abstract}
This paper investigates whether chronic illnesses and injuries have a significant impact on the individual's performance in the labor market. We use the "Santé et Itinéraires Professionnels" (SIP, "Health and Labor Market Histories") survey, conducted in France in 2006-2007. We use the propensity score method in order to evaluate the impact of chronic illnesses and accidents on labor market participation and earnings. We find that both health events have a negative effect on professional careers and earnings, and that accidents have a greater impact on women's earnings.
\end{abstract}

JEL Classification: I10, J20, J31

\section{Introduction}

Illnesses and injuries (such as road or domestic accidents) induce important socio-economic costs such as long-term care, production loss and welfare loss. Concerning employment however, it is difficult to know how serious and how long-lasting the sequels of chronic illness or injuries are and whether their relative impact on work and earnings differs.

The aim of this paper is to investigate whether there is a significant effect of chronic illnesses and injuries on employment (professional trajectories and employment quality) and related earnings. Injuries may be considered generally as random shocks. This is also the case for some diseases which are unrelated to deliberate individual behavior.

A large number of studies have provided evidence on the impact of health on earnings and employment (see Currie, Madrian, 1999 for a survey). The results obtained so far depend partly on the type of samples used, the health measures retained and the econometric methodology used. A widespread result is that health has a greater effect on number of hours worked than on wages (Chikiros, Nestel, 1981, 1985 ; Chirikos, 1993 ; Mitchell, Burkhauser, 1990). For France, evidence has been found on early retirement or on exit from the labor market partially due to health through the

\footnotetext{
1 This research has benefited financial support from Drees and Dares (Research Department of the French Ministry of Labour and Social Affairs). We thank for their comments on earlier versions of this paper: Chantal Cases, Thierry Debrand, François Gardes, Véronique Simonnet, Nicolas Sirven, Christophe Starzec and Claude Mathieu. We also thank the participants to the following seminars and conferences : Health and Safety at Work Conference (Universita Cattolica Milano, July 2010); Journée de Microéconomie Appliquée (University of Angers, June 2010), Journée des Economistes de la Santé Français (University of Lyon, December 2010), Journées d'Etudes sur l'Hétérogénéité des Comportements Individuels (ANR-06-Blan-0140, University of Paris I, April 2011) and the Journée Santé-Travail, (Chaire Santé, Risque Assurance, University of Paris-Dauphine, September 2011).

2 Université Paris Est, ERUDITE and TEPP (FR CNRS 3126) - 61 avenue du Général de Gaulle - 94010 Créteil Cedex - France. Correspondence: emmanuel.duguet@u-pec.fr.

3 Centre d'Etudes de l'Emploi and LAMETA UMR CNRS 5474, ENS Cachan. Email : christine.leclainche@cee-recherche.fr
} 
disability schemes for older people (Barnay (2005); Blanchet, Debrand (2007), Debrand, Sirven (2009); Behaghel, Blanchet, Debrand, Roger (2011). The effect of health on the participation in the labor market and on long-term unemployment from the beginning of the career has been less studied. A paper by Tessier and Wolff (2005) for France shows that health has an impact on work participation from the beginning of the career. Otherwise, a recent paper by Haan and Myck (2009) based on German data found that there are persistent dynamics of both bad health and unemployment. Comparable results were also obtained by Lindeboom, Llena-Nozal and van der Klauw (2006) who stressed the importance of poor living conditions during early childhood ${ }^{4}$.

In most of the studies focusing on the link between health and employment, health is proxied by self-rated health measures. If a number of studies emphasize that the self-rated health measures are well correlated with mortality (see for instance, Idler, Benyamini, 1997) and with the consumption of medical care, the self-rated measures do not always provide a good summary of the severity of diseases (Lanoë, 2005). The main problem which arises in the study of the link between health and employment, using self-rated health measures, is not due to the fact that this measure is not correlated to the underlying health state, since it affects the status in the labor market, but rather that the measurement error does not necessarily result from a random process. There could be a justification bias: the people who diminish their working time or who exit from the labor market are more likely to declare bad health, functional limitations or work-related limitations. Therefore, the studies of the impact of health on employment can be improved when several indicators or various measures of health conditions are used.

Fewer studies seem to have focussed on injuries. In this paper, we consider two kinds of injuries: domestic injuries and road injuries. We set working accidents aside because they imply a higher participation in the labor market before the accident, and this could bias our estimates. ${ }^{5}$

Moller-Dano (2006) investigates whether road injuries have a causal impact on disposable income, earnings, employment and public transfer income in Denmark, using the propensity score matching method. She finds that older injured persons and low income persons have significantly lower disposable incomes than comparable non-injured persons. In the short term as well as in the long term, employment rates are lower for the injured men than for the non-injured men belonging to the reference group. No effect is found for women. Moreover, reduced earnings are found for men in general and for older women.

\footnotetext{
4 A considerable literature takes into account the consequences of early childhood conditions on adult health (Case, Fertig, Paxson (2005); Wadsworth, Butterworth (2006) ; Trannoy, Tubeuf, Jusot, Devaux (2008)).

5 The topic of the interrelation between labor market participation and working accidents is beyond the scope of this paper, and should be part of a specific study including the estimation of a system of LDVs.
} 
Another paper only partially concerning road or other types of injury was conducted by Crichton, Stillman, Hyslop (2011) for New Zealand. They found a strong negative impact of injuries on employment and earnings. The authors also found that long-lasting injuries had more of an impact on women, older workers and those on low-incomes.

In this paper, we compare the impact of chronic illnesses with the impact of injuries on employment and earnings. Our main results are that : (i) childhood living conditions are strongly related to future bad health; (ii) alcohol and tobacco consumption are strongly related to future bad health; (iii) chronic illness and accidents have comparable negative effects on labor market participation and revenues and (iv) women suffer more from accidents than men.

This paper is organized as follows: the second section presents the data and some sample statistics. Section 3 presents the methodology used to identify the effects of illnesses and accidents on the professional career. The fourth section presents the results. The last section concludes.

\section{The data}

We use the "Sante et Itinéraires Professionnels" Survey conducted in France in 2006-2007. This survey collected information about the whole professional career of individuals. It included questions about subjective health: self-rated health but also provided a detailed report of the kinds of disease and symptoms, functional and activity limitations, pain, sleep troubles, mental health- measured by Mini questionnaire- sequels and the employment trajectories (type of contract, working time, duration of employment, change of employment, unemployment) and the related earnings.

The scope of the analysis was restricted to people aged from 19 to 55 . We chose this restriction because, in France, after 55, people can benefit from legal dispositions to exit the labor market ("preretirement"). This device has been reduced recently but was still in application at the time of the survey. We also exclude retired workers and the people who suffer from professional illnesses from the analysis, insofar as our aim is to identify the way health conditions may affect employment and working conditions and not the reverse. Overall, our sample consists of three sub-samples: people with no illnesses or injuries $(\mathrm{N}=4804)$, people with illnesses only $(\mathrm{N}=1105)$ and people with injuries only $(\mathrm{N}=970)$. The total sample size is 6879 .

\section{Measurement of chronic illnesses and injuries}

\section{Chronic or severe illnesses}

In this article, the data available on chronic illnesses provide an improvement over the standard self-declared measures. The chronic illnesses are first declared by the sufferers, but their declarations must pass the definition of long-term diseases provided by the "Sécurite Sociale" (Health Care 
administration). It is so because, in France, such diseases benefit from full reimbursement, so the Health Care administration controls them carefully.

In order to identify the chronic diseases we report on epidemiologists' views of diseases causing limitations (see WHO, IDC) and on the French administrative classification of severe diseases (the socalled "Affections de Longue Durée" or ALD classification). In the SIP survey, the data set is very detailed about the type of disease from which people suffer, in a declarative sense.

We have retained : chronic cardio-vascular diseases, cancers, incurable deafness, chronic hearing impairment (tinnitus), severe or chronic lung diseases, severe or chronic liver diseases, severe or chronic rheumatism, diabetes, severe or chronic eye disorders (impossible to correct) ; severe or chronic psychiatric disorders, epilepsy, addictions, AIDS or other severe diseases.

\section{Sample definition}

Age : 19 to 55 years old

Excluding retired workers

Excluding work-related health problems

We keep the following chronic diseases (SCOD variable)

2, 4, 5,6: cardiovascular diseases

$9:$ cancers

$11,12:$ lung diseases

$16,17:$ deafness, tinnitus

20 : liver disease

23 : slipped disc

28 : bones and articulation diseases

31 : diabetes

35 : eye troubles difficult or impossible to correct

37,38 : severe mental illness

42 : epilepsy

48, 49 : addiction to alcohol and other products (except tobacco)

50 : often HIV

Table 1: Self-reported health and chronic illness dummy variable

\begin{tabular}{lcccc}
\hline Self reported Health & $\begin{array}{c}\text { Reference } \\
\text { sample* } \\
(\mathbf{1})\end{array}$ & $\begin{array}{c}\text { Chronic illness } \\
\text { sample } \\
(\mathbf{2})\end{array}$ & $\begin{array}{c}\text { Difference } \\
\text { (2)-(1) }\end{array}$ & Student $^{* *}$ \\
\hline Very good & $44.7 \%$ & $7.9 \%$ & $-36.8 \%$ & 23.5 \\
Good & $47.8 \%$ & $34.5 \%$ & $-13.2 \%$ & 6.0 \\
Average & $7.2 \%$ & $42.4 \%$ & $+35.1 \%$ & 18.2 \\
Bad & $0.2 \%$ & $12.5 \%$ & $+12.3 \%$ & 11.0 \\
Very bad & $0.1 \%$ & $2.7 \%$ & $+2.6 \%$ & 4.8 \\
\hline * reference sample : no chronic illness and no accident reported; **: All the differences are significant at \\
the 5\% level
\end{tabular}


The indicator that we use is a binary variable indicating the presence or absence of such a chronic disease. In order to assess its quality, we compare it to the self-reported health indicator also available in the survey (Table 1). We find that the chronic illness sample has a much lower selfreported health indicator, since good or very good health pass from $92.5 \%$ in the reference sample to $42.4 \%$ in the chronic illness sample. The percentage of bad or very bad health passes from $0.3 \%$ to $15.2 \%$. However, if we compare the self reported indicator to the types of illness declared by the respondents, there seems to be an excessive declaration of "average health" in the chronic illness sample. This could come from the fact that "average" does not have the same meaning in the reference sample, where no chronic illness or accident is reported, and in the chronic illness sample. This difference provides a motivation to keep the chronic illness dummy variable as our health indicator for this study.

Finally, we also drop the professional chronic diseases since they imply greater participation in the labor market than the total population before the illness appeared, and this selection could have affected our estimates.

\section{Accidents}

To take accidents into account, we use the part of the questionnaire related to accidents, which includes car injuries and domestic accidents.

Finally, we exclude workplace accidents and car accidents occurring during commuting because they involve greater participation in the labor market than in the total population before the accident, and this selection could have affected our estimates.

\section{Descriptive statistics concerning health and injuries}

Table 2 provides the sample statistics. We first compare the people in the reference sample with the people in the chronic illness sample (columns (1), (2), (2)-(1)). The chronic illness sample includes older people and more women. People affected by chronic illness also have a lower level of education (more primary education, less college education) than the people in the reference sample. Looking at childhood living conditions, we find that the people in the chronic illness sample had less often been brought up by their parents than in the reference sample, that their parents more often had serious health problems and that they had more often been separated from their family. The chronic illness sample also shows different risk-related behavior: they drink less than in the reference sample (positive effect on health) and had been more often daily smokers (negative effect on health).

Occupation status and revenues also differ in the chronic illness sample: these people work less than in the reference sample. They have a lower subjective satisfaction index from their career, a higher rate of minimum assistance revenue and appear more often in the lowest revenue class (less than 1200 Euros) and less often in the highest revenue class (more than 4000 Euros). 
The comparison between the accident sample and the reference sample is presented in Columns (1), (3) and (3)-(1). The accident sample includes older people and more men than in the reference sample. The accident sample also includes people with a lower level of education than in the reference sample. The childhood living conditions show significant differences with the reference sample on almost every variable: these people have more often French parents, but had been less often brought up by their parents who had more often serious health problems, and they had been more often separated from their family. Their alcohol and tobacco consumption also differs: they drink more, including to risk levels, and they more often refuse to answer the question on alcohol (the "missing" category), they also smoke more often but on a casual basis.

The injured people have not worked less often, and not worked fewer hours in the week before the survey. However, their subjective satisfaction index about their career is lower than in the reference sample. The injured people also benefit more often from the minimum assistance revenue and are more often in the lowest revenue class and less often in the highest revenue class than the people in the reference sample.

Overall there are significant differences between the reference sample and the chronic illness or accident samples. There are also differences between the chronic illness and the accident samples: the chronic illness sample includes more women and former daily smokers, while the accident sample includes more men with risky alcohol consumption. These first results motivate the following estimation strategy. First, we separate women from men to see whether there is a gender effect; secondly, we perform separate regression for chronic illnesses and accidents since individual behaviors differ regarding alcohol and tobacco; thirdly, we account explicitly for the selection biases since the reference sample does not have the same composition as the chronic illness and accident samples.

\section{Methodology}

Our reference group is not a control group, as the sample statistics show, and this is why we cannot rely fully on the means comparison. We follow the approach initiated by Rosenbaum and Rubin (1983, 1985, see also Rubin (2006)).

We want to measure the effect of bad health (chronic illness or injury) on professional and revenue performance variables. Therefore we should evaluate the difference between the performance that an individual has in bad health and the performance the same individual would have achieved in good health. The latter quantity is called the counterfactual. There are many ways to estimate a counterfactual. In this paper, we consider two families of methods: standard regression analysis ("naive regression estimators") and weighting methods ("evaluation estimators"). The standard 
regression analysis is presented in the Appendix, for comparison, since its estimates are likely to be biased.

Let $\mathrm{y}_{1, \mathrm{i}}$ the performance of individual $i$ in bad health and $\mathrm{y}_{0, \mathrm{i}}$ the performance in good health. The evaluation problem comes from the fact that we cannot observe both quantities at the same time. Either we observe $\mathrm{y}_{1 \mathrm{i}}$ when the individual is in bad health or we observe $\mathrm{y}_{0 \mathrm{i}}$ when (s)he is not. The observable data are therefore:

$$
\mathrm{y}_{\mathrm{i}}=\left(1-\mathrm{T}_{\mathrm{i}}\right) \mathrm{y}_{0 \mathrm{i}}+\mathrm{T}_{\mathrm{i}} \mathrm{y}_{1 \mathrm{i}} \text { with } T_{i}=\left\{\begin{array}{cc}
1 & \text { with a bad health } \\
0 & \text { otherwise }
\end{array}\right.
$$

\section{Standard regression analysis}

The methods in this section are useful mostly because they allow us to assess the biases associated with them. The simplest method is the "naïve estimator" equal to the difference between the average performance of the individuals in bad health and in good health. Technically this reduces to performing an OLS regression of the performance variables on the intercept and a bad health dummy variable (equal to 1 for bad health, 0 for good health). The OLS coefficient of the bad health dummy variable gives the difference of the mean performances in both groups:

$$
\hat{\mathrm{c}}=\frac{1}{\mathrm{~N}_{1}} \sum_{\mathrm{i} \in \mathrm{I}_{1}} \mathrm{y}_{\mathrm{i}}-\frac{1}{\mathrm{~N}_{0}} \sum_{\mathrm{i} \in \mathrm{I}_{0}} \mathrm{y}_{\mathrm{i}}
$$

where $I_{1}$ is the index set of the bad health individuals (number: $N_{1}$ ), and $I_{0}$ the index set of the good health individuals (number $\mathrm{N}_{0}$ ). A second method extends the previous model by adding control variables $\mathrm{X}_{\mathrm{i}}$, such as childhood living conditions, into the previous regression. The model becomes:

$y_{i}=a+X_{i} b+c T_{i}+u_{i}$, where $u_{i}$ is the usual disturbance, assumed uncorrelated with the explanative variables.

From this model, we derive two quantities: First, for $T_{i}=0$, we obtain an expected average performance $\mathrm{E}\left(\mathrm{y}_{\mathrm{i}} \mid \mathrm{T}_{\mathrm{i}}=0\right)=\mathrm{a}+\mathrm{X}_{\mathrm{i}} \mathrm{b}$, and, second, for $\mathrm{T}_{\mathrm{i}}=1$, we get the expected average performance $\mathrm{E}\left(\mathrm{y}_{\mathrm{i}} \mid \mathrm{T}_{\mathrm{i}}=1\right)=\mathrm{a}+\mathrm{X}_{\mathrm{i}} \mathrm{b}+\mathrm{c}$. This implies that the effect of bad health for the individual $i$ is equal to:

$$
\mathrm{E}\left(\mathrm{y}_{\mathrm{i}} \mid \mathrm{T}_{\mathrm{i}}=1\right)-\mathrm{E}\left(\mathrm{y}_{\mathrm{i}} \mid \mathrm{T}_{\mathrm{i}}=0\right)=\mathrm{c}
$$


Compared with the naïve estimator, this regression allows us to correct for the part of the performance difference that is attributable to the control variables $X_{i}$. But, strictly speaking, this estimator is not fully consistent with the evaluation problematic even when there is no selection bias. A third regression method is more rigorous. We assume that there are two equations corresponding to each of the potential outcomes, so that:

$$
\mathrm{y}_{0 \mathrm{i}}=\mathrm{a}_{0}+\mathrm{X}_{\mathrm{i}} \mathrm{b}_{0}+\mathrm{u}_{0 \mathrm{i}} \text { and } \mathrm{y}_{1 \mathrm{i}}=\mathrm{a}_{1}+\mathrm{X}_{\mathrm{i}} \mathrm{b}_{1}+\mathrm{u}_{1 \mathrm{i}}
$$

And the observable performance is:

$$
\mathrm{y}_{\mathrm{i}}=\left(1-\mathrm{T}_{\mathrm{i}}\right) \mathrm{y}_{0 \mathrm{i}}+\mathrm{T}_{\mathrm{i}} \mathrm{y}_{1 \mathrm{i}}=\left(1-\mathrm{T}_{\mathrm{i}}\right)\left(\mathrm{a}_{0}+\mathrm{X}_{\mathrm{i}} \mathrm{b}_{0}+\mathrm{u}_{0 \mathrm{i}}\right)+\mathrm{T}_{\mathrm{i}}\left(\mathrm{a}_{1}+\mathrm{X}_{\mathrm{i}} \mathrm{b}_{1}+\mathrm{u}_{1 \mathrm{i}}\right),
$$

After some simplification, we get:

$$
y_{i}=\beta_{0}+X_{i} \beta_{1}+T_{i} \beta_{2}+T_{i} X_{i} \beta_{3}+u_{i}
$$

With $\beta_{0}=a_{0}, \beta_{1}=b_{0}, \beta_{2}=a_{1}-a_{0}, \beta_{3}=b_{1}-b_{0}, u_{i}=\left(1-T_{i}\right) u_{0 i}+T_{i} u_{1 i}$

which implies that one should estimate a model with all the cross products of the control variables with the bad health dummy. Moreover, if the variables $\mathrm{X}_{\mathrm{i}}$ are centered, we can show that the coefficient of the bad health dummy, $\beta_{2}$, measures the average effect of bad health on the performance. The structure of this model also implies that the disturbance of the model is heteroskedastic since the disturbance is different depending on $T_{i}=0$ or $T_{i}=1$. We account for this property in our estimations.

\section{Evaluation methods}

The "evaluation methods" are the most important in this paper since the naive regression methods do not account for the fact that the individuals are not comparable in the bad health and good health groups. We follow the propensity score matching approach initiated by Rosenbaum and Rubin (1983, 1985) and surveyed in Lee (2005) and Rubin (2006). The usual parameter of interest in the literature is the average effect of the treatment on the treated (henceforth, ATT) defined as:

$$
\mathrm{ATT}=\mathrm{E}\left(\mathrm{y}_{1}-\mathrm{y}_{0} \mid \mathrm{T}=1\right)=\mathrm{E}\left(\mathrm{y}_{1} \mid \mathrm{T}=1\right)-\mathrm{E}\left(\mathrm{y}_{0} \mid \mathrm{T}=1\right)
$$

But the ATT cannot be identified without further assumptions, since $\mathrm{E}\left(\mathrm{y}_{0} \mid \mathrm{T}=1\right)$ is not observable. The assumption of random selection is not satisfied in our study because there are a 
number of characteristics which may influence both the health status and the performance variables. Conditioning on a vector of covariates X, the ATT becomes:

$$
\operatorname{ATT}(\mathrm{X})=\mathrm{E}\left(\mathrm{y}_{1}-\mathrm{y}_{0} \mid \mathrm{T}=1, \mathrm{X}\right)=\mathrm{E}\left(\mathrm{y}_{1} \mid \mathrm{T}=1, \mathrm{X}\right)-\mathrm{E}\left(\mathrm{y}_{0} \mid \mathrm{T}=1, \mathrm{X}\right)
$$

where $\mathrm{X}$ is a vector of control variables that are not affected by the treatment. In this first paper, we consider matching on observables in order to identity a causal treatment effect on the treated (see for instance, Deheija and Wahba, 2002). The ATT may be identified by introducing the Conditional Independence Assumption:

$$
\mathrm{E}\left(\mathrm{y}_{0} \mid \mathrm{T}=1, \mathrm{X}\right)=\mathrm{E}\left(\mathrm{y}_{0} \mid \mathrm{T}=0, \mathrm{X}\right)
$$

This assumption implies that, conditional on $\mathrm{X}$, the expected potential outcome in the case of non-treatment is the same for both treated and non treated groups. Thus the observed outcome for bad health people may be used to measure the potential outcome for good health people conditional on the individual characteristics $\mathrm{X}$.

When the set of observed characteristics is large enough, matching should enable us to consistently estimate the causal effects of bad health on the performance variables. Rosenbaum and Rubin (1983) show that instead of conditioning on a high-dimension X, control for covariates can be obtained by controlling for a real-valued function of $\mathrm{X}, \mathrm{P}(\mathrm{X})$, called the propensity score. It is defined as the probability of getting treatment (i.e, to be in bad health, in our study). This implies that:

$$
\mathrm{E}\left(\mathrm{Y}_{0} \mid \mathrm{T}=1, \mathrm{P}(\mathrm{X})\right)=\mathrm{E}\left(\mathrm{Y}_{0} \mid \mathrm{T}=0, \mathrm{P}(\mathrm{X})\right)
$$

The intuition of this result is the following: if two individuals have the same probability of being in bad health, and the first individual is in bad health while the other is not, then the allocation of bad health can be considered as random between these two individuals, and we can use the second individual as a counterfactual for the first individual.

Last, in order to ensure that our estimators have relevant empirical content, we need to account for a last constraint: the individuals in the treatment group and in the control group must have similar probabilities of getting treatment. Therefore we make all our estimations on the common support of the treatment probabilities. More precisely, once we have estimated the individual probabilities of being in bad health, we define the supports of the probabilities on the treated and not treated groups by the $1^{\text {st }}$ and $99^{\text {th }}$ percentiles (to avoid outliers). Then we take the intersection of these two supports. This implies that the comparisons can only be made on a part of the sample: the individuals that have probabilities of bad health close to 0 or 1 must be excluded from the evaluation. In practice, we find that between $84 \%$ and $94 \%$ of the individuals can be compared, depending on the sub-sample we 
consider (some performance variables are defined on subsets of the data only, so that this rate can differ).

There are several ways to apply the propensity score methodology: the most common are kernel matching and weighting. We have retained the second methodology in this paper. One reason is that kernel matching is often applied with non optimal windows and non optimal kernels, and requires the use of the bootstrap for evaluating the standard errors, therefore leading to less accuracy and longer computing time. ${ }^{6}$ The weighting approach uses the same assumptions as kernel matching, but merely expresses the non observable sample moments by their observable counterparts, and replaces them by the corresponding empirical moments. We get the following results:

a/ Average effect of the treatment on the not treated :

$$
\mathrm{c}_{0}=\frac{1}{\mathrm{~N}^{\mathrm{c}}} \sum_{\mathrm{i}=1}^{\mathrm{N}^{\mathrm{c}}}\left(\frac{\mathrm{N}_{0}^{\mathrm{c}}}{\mathrm{N}^{\mathrm{c}}}\right)^{-1} \mathrm{y}_{\mathrm{i}}\left(\frac{\mathrm{T}_{\mathrm{i}}}{\pi_{\mathrm{i}}}-1\right)
$$

b/ Average effect of the treatment on the treated:

$$
\mathrm{c}_{1}=\frac{1}{\mathrm{~N}^{\mathrm{c}}} \sum_{\mathrm{i}=1}^{\mathrm{N}^{\mathrm{c}}}\left(\frac{\mathrm{N}_{0}^{\mathrm{c}}}{\mathrm{N}^{\mathrm{c}}}\right)^{-1} \mathrm{y}_{\mathrm{i}}\left(\frac{\mathrm{T}_{\mathrm{i}}-\pi_{\mathrm{i}}}{1-\pi_{\mathrm{i}}}\right)
$$

c/ Average effect of the treatment on the whole population :

$$
\mathrm{c}=\frac{1}{\mathrm{~N}^{\mathrm{c}}} \sum_{\mathrm{i}=1}^{\mathrm{N}^{\mathrm{c}}} \mathrm{y}_{\mathrm{i}}\left(\frac{\mathrm{T}_{\mathrm{i}}-\pi_{\mathrm{i}}}{\pi_{\mathrm{i}}\left(1-\pi_{\mathrm{i}}\right)}\right)
$$

Where $\pi_{\mathrm{i}}$ is the value of the propensity score for the individual $i, \mathrm{~N}^{\mathrm{c}}$ the number of individuals in the common support, $\mathrm{N}_{0}^{\mathrm{c}}$ the number of not treated in the common support and $\mathrm{N}_{1}^{\mathrm{c}}$ the corresponding number of treated individuals. In practice, we do not know the exact value of $\pi_{\mathrm{i}}$, so that we have to replace it by a consistent estimator. In our application, we use a Probit model estimated by the maximum likelihood method, and get a prediction $\hat{\pi}_{\mathrm{i}}$ of the propensity score, which is used for the evaluation. This clearly affects the variance of the evaluation parameters in the following way.

All our estimators can be written in the following form:

\footnotetext{
${ }^{6}$ In practice, this could be fixed by taking an adaptative Epanechnikov kernel and cross validation on the full sample.
} 


$$
\hat{\theta}=\frac{1}{N^{c}} \sum_{i=1}^{N^{c}} y_{i} g_{i}(\hat{b})
$$

where $\hat{b}$ is the estimated parameter from the Probit model. Using the delta method, we can estimate the variance of our estimate by:

$$
\hat{\mathrm{V}}(\hat{\theta})=\frac{1}{\mathrm{~N}^{\mathrm{c}}} \sum_{\mathrm{i}=1}^{\mathrm{N}^{\mathrm{c}}}\left(\hat{\varphi}_{\mathrm{i}}-\overline{\hat{\varphi}}\right)^{2}
$$

with

$$
\hat{\varphi}_{i}=y_{i} g_{i}(\hat{b})+\frac{1}{N^{c}} \sum_{i=1}^{N^{c}}\left[y_{i} \frac{\partial g_{i}}{\partial b^{\prime}}(\hat{b})\right] J_{1}(\hat{b})^{-1} \sqrt{N^{c}} s_{i}(\hat{b})
$$

where :

$$
J_{1}(b)=E\left[-\frac{\partial^{2} \ln f}{\partial b \partial b^{\prime}}(T \mid X, b)\right], s_{i}(b)=\frac{\partial \ln f\left(T_{i} \mid X_{i}, b\right)}{\partial b}
$$

and

$$
\ln f\left(\mathrm{~T}_{\mathrm{i}} \mid \mathrm{X}_{\mathrm{i}}, \mathrm{b}\right)=\mathrm{T}_{\mathrm{i}} \ln \Phi\left(\mathrm{X}_{\mathrm{i}} \mathrm{b}\right)+\left(1-\mathrm{T}_{\mathrm{i}}\right) \ln \left(1-\Phi\left(\mathrm{X}_{\mathrm{i}} \mathrm{b}\right)\right)
$$

Notice that these formulas are valid for any binary model estimated by the maximum likelihood method, provided that one replaces $\Phi\left(\mathrm{X}_{\mathrm{i}} \mathrm{b}\right) \Phi$ by $1-\mathrm{F}\left(-\mathrm{X}_{\mathrm{i}} \mathrm{b}\right)$ where $\mathrm{F}($.$) is the cdf of the$ disturbance of the new model (or by $\mathrm{F}\left(\mathrm{X}_{\mathrm{i}} \mathrm{b}\right)$ if the distribution of the new model is symmetric).

\section{Results}

All the regressions are performed separately for men and women, for several reasons. Among the reasons, men and women do not occupy the same types of job in the labor market, and they do not have the same probabilities of getting some chronic illnesses, such as the different types of cancer. They are also paid different wages, and the predominant role of women in the education of children may affect their labor market participation compared to men. By separating men from women, we wish to increase the homogeneity of both our health and performance variables.

\section{Propensity scores for chronic illness}

Table 3 presents the Probit regression results on the probability of getting a chronic illness. The predictions of this model are the propensity scores used in Table 5. The determinants of chronic 
illness for women are analyzed in the first three columns. The average effect gives the variation in percentage points compared to the reference level. ${ }^{7}$ The probability of chronic illness increases with age $(+15.8 \%$ for the age class 46-55 compared to 19-27), the fact that the parents had serious health problems $(+8.2 \%)$, when the girl had been separated from her family $(+5.9 \%)$ and when the woman was a former daily smoker (+5.2\%). The probability of getting a chronic illness decreases with the level of education (-4.7\% to -7.4\%) and when the girl was brought by her mother (-7\%). We also find that casual alcohol consumption, compared to the other types of alcohol consumptions, reduces the probability of chronic illness (-4.5\%). One explanation may be that choosing casual consumption would be associated with a more cautious attitude towards alcohol. Overall, chronic illness among women would originate partly from genetic factors, here measured by the health status of the parents, but also from childhood living conditions, the level of education reached, daily smoking and age.

The determinants of chronic illness for men are analyzed in the three last columns of Table 3. The probability of getting a chronic illness increases with age $(+18.1 \%$ for the age class 46-55 compared to 19-27), the fact that the parents had serious health problems (+4.7\%), and decreases with the level of education (between $-7.7 \%$ and $-8.3 \%$ ). No effect is found for (self-reported) alcohol and tobacco consumptions.

Overall, men and women share important determinants in common: the probability of getting a chronic illness increases with age and when the parents had serious health problems; it decreases with the level of education. Women differ from men on three points: they suffer more from past daily smoking, from being separated from their family when they were young, and less when they have been brought up by their mother.

\section{Propensity scores for accidents}

Table 4 presents the Probit estimates for accidents. The estimates for women are shown in the first three columns. The probability of having an accident for women increases with being in the oldest age class (46-55: $+12.3 \%)$, when parents had serious health problems $(+8.0 \%)$, when the girl was separated from her family (+9.8\%) and when the woman was a former daily smoker $(+4.0 \%)$. Being a former daily smoker could be related to more risky attitudes in general. The probability of having an accident decreases when the woman had a foreign father (-8.4\%) and with the level of education. We think that the last two results could be related to the possession of a driving license. About the first result, we assume, cautiously, that the women having a foreign father would be less likely to take their driving test for cultural reasons. Most immigrants in France come from Africa, where women more often depend on their father or brothers for driving. The fact that they would drive less often would explain why they have fewer accidents. The second result, showing that women with at least three years of college education would have a higher probability of having an accident than less educated

\footnotetext{
7 With our convention, one adds the average effect to the reference group probability indicated in the Table. For instance, women aged 28-36 have an increase of 4.9 points of their probability of getting a chronic illness, compared to the women aged 19-27.
} 
women, can also be related to a higher likelihood of possessing a driving license. This would come from greater and more independent revenue sources, as well as from their professional requirements.

The determinants of the probability of having an accident for men are presented in the last three columns of Table 4. The probability of a man having an accident increases with all the age classes $($ from $+6.3 \%$ to $+16.5 \%)$, the fact that his parents had serious health problems $(+13.3 \%)$, and chronic alcoholism (+11.4\%). The probability decreases with being a casual smoker (-8.8\%). The last two results can be related to the individual behavior toward risk: while being a casual smoker reveals caution towards risk, chronic drinking clearly goes in the other direction. We would just find that the men with the more risky attitudes in their everyday life would experience more accidents than the other men.

Overall, there seems to be less difference between men and women regarding accidents than for chronic diseases. The main difference is that women suffer more from being separated from their family.

Tables 3 and 4 also give us a clear message: the illness and accident samples are not balanced, so that one cannot compare them with the reference sample directly. We use matching methods to tackle this problem. Our comments will focus on the ATT, the average treatment effect on the treated, which corresponds here to the average effect of bad health on the performance of the people in bad health.

\section{Impact of illness on performance measures}

Table 5 presents the effects of chronic illness on our performance variables. A first performance variable refers to the end-of-period occupational status and to the subjective satisfaction index over the whole professional career. The second set of variables relates to the end-of-period incomes, with a dummy variable of being a recipient of the minimum assistance revenue, and the revenue class. In this performance analysis, we also restrict ourselves to end-of-period variables.

The effect (ATT) of chronic illnesses for women is significantly negative on both present occupation and the judgment about the whole professional career. The stronger effects relate to the present employment status: ill women had less often been working the week before the survey (-4.7\%) and had been working fewer hours. They also have a lower subjective satisfaction index about their whole career than they would have had if in good health. Regarding revenues, ill women are more often in the lowest revenue class and less often in the highest revenue class.

The effect (ATT) of chronic illnesses for men is similar to women. Common points first. Ill men had also less often been working during the week before the survey (-6.6\%) and had been working fewer hours. Secondly, they have a lower subjective satisfaction index about their whole professional career than they would have if in good health and, thirdly, they are more often in the lowest revenue class and less often in the highest revenue class. 
Overall, chronic illnesses reduce activity, the number of hours worked and the revenues of both men and women. The activity and revenue losses are of a comparable order of magnitude for both.

Impact of accidents on performance measures

Table 6 presents the effects of accidents on the performance variables. Injured women had been working less often the week before the survey (-6.0\%). Their subjective satisfaction index about their whole professional career is lower when they have had an accident (at the $10 \%$ level). It also appears that there are significant differences on the revenues. Injured women are more often the recipient of the minimum assistance revenue (+5.4\%). They are more often in the lowest revenue class $(+9.4 \%)$ and less often in the highest revenue class than they would have been if they hadn't had an accident ($4.9 \%$ in $2500-4000 €$ and $-2.8 \%$ above $4000 €)$.

The effect of an accident for men is similar except for revenues. Injured men had been working less often the week before the survey (-6.0\%) and have a lower satisfaction index about their whole professional career. But men do not have a higher probability of getting the minimum assistance revenue and their end-of-period revenue is higher than women's. They have a higher probability of being in the lowest revenue class ( $+3.9 \%$ against $+9.4 \%$ for women) and a smaller probability of reaching the highest revenue class (-5.3\%). In particular, they do not have a lower probability of being in the 2500-4000 € class, in contrast to women.

Overall, accidents reduce activity and revenues, but not the number of hours worked. They also have a greater impact on women's revenues than on men's revenues.

Comparison with regression estimators

The Appendix provides the OLS estimators in Tables A-1 and A-2. We find that the methods show some differences but that, overall, the OLS estimators are close to the ATE estimator (the average effect over the whole population). Therefore some wrong conclusion can emerge when the ATE is different from the ATT. The most important difference is that the OLS estimator fails to indicate that women have a lower probability of being in the two highest revenue classes when they have had an accident. 


\section{Conclusion}

In this article we look at whether and how chronic illnesses and accidents impact individual labor market performance. First we find that childhood living conditions and the health status of the parents have a strong effect on the individual probabilities of being in bad health. Secondly, we find that health events in general reduce the end-of-period participation in the labor market, the subjective satisfaction index about the whole career and the revenues. The predominance of ill and injured persons in the lowest part of the income distribution suggests than they face lower-wage and probably less stable jobs than the ones they would have had without the bad health event.

We also find differences related to the type of bad health and to gender. First, chronic illnesses reduce both labor market participation and the number of hours worked, while accidents reduce labor market participation only. Secondly, the most important difference that we find is between genders. Women who have had an accident suffer more from revenue losses than men. The latter result suggests a gender inequality regarding health consequences in the labor market. 


\section{References}

Barnay T. (2005), « Santé déclarée et cessation d'activité », Revue Française d'Economie, vol.XX, $n^{\circ}$ 2, pp. 73-106.

Blanchet D., Debrand T. (2007), Souhaiter prendre sa retraite le plus tôt possible : Santé, satisfaction au travail et facteurs monétaires (Wanting to Retire as Early as Possible: Health, Job Satisfaction and Monetary Factors), Economie et Statistique, $n^{\circ} 403-404, p p$. 39-62.

Debrand T., Sirven N. (2009), What are the Motivations of Pathways to Retirement in Europe : Individual, Familial, Professional Situation of Social Protection Systems, Working Paper Irdes $n^{\circ}$ 28. 2009/10.

Behaghel L., Blanchet D., Debrand T., Roger M. (2011), "Disability and Social Security Reforms : The French Case”, NBER Working Paper $n^{\circ} 17055$, May.

Case A., Fertig A., Paxson C.(2005), "The Lasting Impact of Childhood Health and Circumstance”, Journal of Health Economics, vol. 24, pp.365-389.

Chirikos T. N., Nestel G.(1981), "Impairment and Labor Market Outcomes : A Cross Sectional and Longitudinal Analysis"in Parnes H.S. (ed.), “Work and Retirement : A Longitudinal Study of Men”, MIT Press, Cambridge, pp. 91-131.

Chirikos T. N., Nestel G.(1985), "Further evidence on the economic effects of poor health", Review of Economics and Statistics vol. 67, pp. 61-69.

Chirikos T.N (1993). "The Relationship Between Health and Labor Market Status". Annual Review of Public Health vol. 14 pp. 293-312.

Crichton S., Stillman S., Hyslop D.(2011), “Returning to Work from Injury: Longitudinal Evidence on Employment and Earnings", Industrial and Labor Relations Review vol. $64 n^{\circ} 4$, July, art.7.

Currie J., Madrian B. (1999), Health, Health Insurance and the Labor Market, in Ashenfelter O., Card D.(eds), Handbook of Labor Economics, vol. 3, chap. 50, p. 3309-3416.

Dehejia R. et Wabba S., 2002, «Propensity Score Matching Methods for Non-Experimental Causal Studies", Review of Economics and Statistics, 84, 151-161.

Haan P., Myck M. (2009), "Dynamics of Poor Health and Non-Employment”, Discussion Paper $n^{\circ}$ 4154, April, IZA.

Idler E. L., Benyamini Y.(1997), "Self-rated health and mortality: a Review of twenty - seven communities studies", Journal of Health and Social Behaviour, vol. 38, pp. 21-37.

Lanoë J.L. (2005), L'Etat de santé en France en 2003. Santé perçue, morbidité déclarée et recours aux soins à travers l'enquête décennale santé, Etudes et Résultats $n^{\circ} 436$, octobre, DREES.

Lee Myoung-Jae (2005). Micro-Econometrics for Policy, Program and Treatment Effects. Oxford University Press. ISBN 0199267685.

Lindeboom M., Llena-Nozal A., van der Klauw B. (2006), "Disability and Work”, Tinbergen Institute Discussion Paper 039/03.

Mitchell J. M., Burkhauser R. (1990), «Disentangling the Effect of Arthrisis on Earnings : A Simultaneous Estimate of Wage Rates and Hours Worked", Applied Economics, vol. 22, pp. 12911310.

Moller-Dano A.M. (2005), "Road Injuries and Long Run Effects on Income and Employment", Health Economics, vol. 14, $n^{\circ}$ 9, pp. 955-970

Rosenbaum P.R., Rubin D., 1983, "The Central Role of the Propensity Score in Observational Studies for Causal Effects, Biometrika, 70 (1), 41-55

Rosenbaum P. and D. Rubin (1985). Constructing a control group using multivariate matched sampling methods that incorporate the propensity score. The American Statistician; vol. 39, $n^{\circ} 1$, 33-38.

Rubin D. (2006). Matched sampling for causal effects. Cambridge University Press, ISBN : 9780521674362. 
Trannoy A., Tubeuf S., Jusot F., Devaux M. (2008), "Inequality of Opportunities in health in France: A first Pass", HEDG WP 08/24, October .

Wadsworth M., Butterworth S. (2006), "Early Life", in Marmot M., Wilkinson R. (2006), Social Determinants of Health, Oxford University Press, Chap. 3, 31-53 
Table 2: Sample statistics

**: the difference is significant at the $5 \%$ level; * : the difference is significant at the $10 \%$ level.

\begin{tabular}{|c|c|c|c|c|c|c|c|}
\hline Variables & $\begin{array}{l}\text { Reference } \\
\text { sample } \\
\text { (1) }\end{array}$ & $\begin{array}{l}\text { Chronic } \\
\text { illness } \\
\text { sample } \\
\text { (2) } \\
\end{array}$ & $\begin{array}{l}\text { Difference } \\
\text { (2)-(1) }\end{array}$ & $\begin{array}{l}\text { Student } \\
\text { (2)-(1) }\end{array}$ & $\begin{array}{c}\text { Accident } \\
\text { sample } \\
\text { (3) }\end{array}$ & $\begin{array}{l}\text { Difference } \\
\text { (3)-(1) }\end{array}$ & $\begin{array}{l}\text { Student } \\
(3)-(1)\end{array}$ \\
\hline \multicolumn{8}{|l|}{ Gender } \\
\hline Women & $56.8 \%$ & $62.4 \%$ & $5.5 \%$ & $3.28^{* *}$ & $44.5 \%$ & $-12.3 \%$ & $5.57^{* *}$ \\
\hline \multicolumn{8}{|l|}{ Age } \\
\hline $19-27$ & $19.4 \%$ & $10.3 \%$ & $-9.0 \%$ & $8.08^{* *}$ & $11.3 \%$ & $-8.0 \%$ & $5.74^{\star *}$ \\
\hline $28-36$ & $24.1 \%$ & $16.9 \%$ & $-7.2 \%$ & $5.42^{* *}$ & $18.9 \%$ & $-5.3 \%$ & $3.06^{\star *}$ \\
\hline $37-45$ & $28.8 \%$ & $27.5 \%$ & $-1.3 \%$ & 0.87 & $26.5 \%$ & $-2.3 \%$ & 1.16 \\
\hline $46-55$ & $27.7 \%$ & $45.3 \%$ & $17.6 \%$ & $10.37^{* *}$ & $43.3 \%$ & $15.6 \%$ & $6.99^{* *}$ \\
\hline \multicolumn{8}{|l|}{ Highest degree } \\
\hline Missing & $13.0 \%$ & $14.9 \%$ & $2.0 \%$ & 1.60 & $12.4 \%$ & $-0.6 \%$ & 0.39 \\
\hline Primary education & $2.8 \%$ & $7.4 \%$ & $4.5 \%$ & $5.28^{* *}$ & $3.9 \%$ & $1.1 \%$ & 1.05 \\
\hline Secondary education (professional) & $5.4 \%$ & $6.8 \%$ & $1.3 \%$ & 1.55 & $9.1 \%$ & $3.6 \%$ & $2.99^{* *}$ \\
\hline Secondary education (general) & $29.1 \%$ & $31.7 \%$ & $2.6 \%$ & 1.64 & $33.2 \%$ & $4.1 \%$ & $1.94^{*}$ \\
\hline Professional baccalauréat (O-level. professional) & $10.0 \%$ & $8.5 \%$ & $-1.6 \%$ & 1.59 & $7.9 \%$ & $-2.1 \%$ & $1.68^{*}$ \\
\hline General baccalauréat (O-level. general) & $7.6 \%$ & $8.6 \%$ & $0.9 \%$ & 0.95 & $7.1 \%$ & $-0.5 \%$ & 0.44 \\
\hline Two years of college education & $13.6 \%$ & $8.7 \%$ & $-4.9 \%$ & $4.84^{* *}$ & $10.0 \%$ & $-3.6 \%$ & $2.73^{* *}$ \\
\hline At least three years of college education & $18.4 \%$ & $13.5 \%$ & $-4.9 \%$ & $4.04^{* *}$ & $16.4 \%$ & $-2.1 \%$ & 1.28 \\
\hline \multicolumn{8}{|l|}{ Childhood } \\
\hline Foreign mother & $15.8 \%$ & $15.4 \%$ & $-0.4 \%$ & 0.32 & $13.2 \%$ & $-2.6 \%$ & $1.67^{*}$ \\
\hline Foreign father & $15.0 \%$ & $15.7 \%$ & $0.7 \%$ & 0.55 & $11.2 \%$ & $-3.8 \%$ & $2.47^{\star *}$ \\
\hline Born in France & $88.2 \%$ & $87.6 \%$ & $-0.7 \%$ & 0.58 & $88.1 \%$ & $-0.1 \%$ & 0.05 \\
\hline Brought up by the mother & $96.6 \%$ & $94.1 \%$ & $-2.5 \%$ & $3.12^{* *}$ & $94.5 \%$ & $-2.1 \%$ & $1.97^{\star *}$ \\
\hline Brought up by the father & $88.9 \%$ & $86.5 \%$ & $-2.4 \%$ & $2.06^{* *}$ & $85.4 \%$ & $-3.5 \%$ & $2.25^{\star *}$ \\
\hline Parents had serious health problems & $12.1 \%$ & $18.1 \%$ & $6.1 \%$ & $4.65^{\star *}$ & $22.7 \%$ & $10.6 \%$ & $5.86^{* *}$ \\
\hline Separated from the family & $10.8 \%$ & $15.7 \%$ & $4.9 \%$ & $3.95^{\star *}$ & $19.0 \%$ & $8.1 \%$ & $4.77^{\star *}$ \\
\hline \multicolumn{8}{|l|}{ Alcohol consumption } \\
\hline Missing & $12.2 \%$ & $13.3 \%$ & $1.2 \%$ & 1.00 & $16.2 \%$ & $4.0 \%$ & $2.52^{* *}$ \\
\hline Not drinking & $18.5 \%$ & $22.5 \%$ & $4.0 \%$ & $2.78^{* *}$ & $14.0 \%$ & $-4.5 \%$ & $2.60^{\star *}$ \\
\hline Without risk & $42.9 \%$ & $43.8 \%$ & $0.9 \%$ & 0.50 & $41.2 \%$ & $-1.7 \%$ & 0.76 \\
\hline At risk. casual & $22.8 \%$ & $16.9 \%$ & $-5.9 \%$ & $4.42^{* *}$ & $21.6 \%$ & $-1.1 \%$ & 0.64 \\
\hline At risk. chronic & $3.6 \%$ & $3.5 \%$ & $-0.1 \%$ & 0.22 & $6.9 \%$ & $3.3 \%$ & $3.29^{* *}$ \\
\hline \multicolumn{8}{|l|}{ Tobacco consumption } \\
\hline Missing & $10.9 \%$ & $10.8 \%$ & $0.0 \%$ & 0.04 & $14.9 \%$ & $4.1 \%$ & $2.69^{\star *}$ \\
\hline Not smoking & $50.1 \%$ & $48.4 \%$ & $-1.7 \%$ & 0.98 & $42.7 \%$ & $-7.4 \%$ & $3.30^{\star *}$ \\
\hline Former daily smoker & $9.7 \%$ & $11.7 \%$ & $2.1 \%$ & $1.89^{*}$ & $11.9 \%$ & $2.2 \%$ & 1.51 \\
\hline Casual smoker & $5.5 \%$ & $5.0 \%$ & $-0.5 \%$ & 0.66 & $3.4 \%$ & $-2.1 \%$ & $2.30^{\star *}$ \\
\hline Daily smoker & $23.9 \%$ & $24.1 \%$ & $0.2 \%$ & 0.11 & $27.1 \%$ & $3.2 \%$ & 1.63 \\
\hline \multicolumn{8}{|l|}{ Location: } \\
\hline Lives in underprivileged suburbs & $6.7 \%$ & $6.8 \%$ & $0.1 \%$ & 0.07 & $7.1 \%$ & $0.4 \%$ & 0.36 \\
\hline \multicolumn{8}{|l|}{ Activity } \\
\hline Has been working last week & $76.5 \%$ & $70.6 \%$ & $-5.9 \%$ & $3.76^{* *}$ & $75.4 \%$ & $-1.2 \%$ & 0.58 \\
\hline Number of hours worked last week (if >0) & 38.53 & 36.31 & -2.22 & $4.73^{* *}$ & 38.17 & -0.36 & 0.60 \\
\hline \multicolumn{8}{|l|}{ Subjective satisfaction degree of the career } \\
\hline Missing & $5.4 \%$ & $3.9 \%$ & $-1.5 \%$ & $2.22^{* *}$ & $2.1 \%$ & $-3.4 \%$ & $4.40^{\star *}$ \\
\hline Subjective satisfaction index & 7.40 & 6.86 & -0.53 & $6.10^{* *}$ & 6.99 & -0.40 & $3.57^{* *}$ \\
\hline \multicolumn{8}{|l|}{ Revenues } \\
\hline $\begin{array}{l}\text { Minimum assistance revenue last month } \\
\text { Average monthly earnings of the household: }\end{array}$ & $2.6 \%$ & $4.8 \%$ & $2.2 \%$ & $3.09^{* *}$ & $4.9 \%$ & $2.4 \%$ & $2.44^{* *}$ \\
\hline
\end{tabular}


Missing

Less than 1200 Euros

1200-2500 Euros

2500-4000 Euros

More than 4000 Euros

Sample size (individuals)

\begin{tabular}{ccccccc}
$4.3 \%$ & $3.6 \%$ & $-0.7 \%$ & 1.08 & $2.2 \%$ & $-2.1 \%$ & $2.83^{* *}$ \\
$13.3 \%$ & $20.1 \%$ & $6.8 \%$ & $5.00^{* *}$ & $19.5 \%$ & $6.2 \%$ & $3.43^{* *}$ \\
$39.4 \%$ & $39.2 \%$ & $-0.2 \%$ & 0.13 & $39.5 \%$ & $0.1 \%$ & 0.03 \\
$29.5 \%$ & $27.5 \%$ & $-2.1 \%$ & 1.32 & $27.7 \%$ & $-1.8 \%$ & 0.89 \\
$13.4 \%$ & $9.7 \%$ & $-3.8 \%$ & $3.60^{* *}$ & $11.1 \%$ & $-2.3 \%$ & $1.68^{*}$ \\
\hline 4804 & 1005 & - & - & 970 & - & - \\
\hline
\end{tabular}


Table 3: Probability of getting a chronic illness

Maximum likelihood estimation of the Probit model. ** : significant at the 5\% level; *: significant at the $10 \%$ level

\begin{tabular}{|c|c|c|c|c|c|c|}
\hline & \multicolumn{3}{|c|}{ Women } & \multicolumn{3}{|c|}{ Men } \\
\hline & Parameter & $P$ value & $\begin{array}{c}\text { Average } \\
\text { effect }\end{array}$ & Parameter & $P$ value & $\begin{array}{c}\text { Average } \\
\text { effect }\end{array}$ \\
\hline Intercept & $-1.111^{* *}$ & 0.000 & & $-1.343^{* *}$ & 0.000 & \\
\hline \multicolumn{7}{|l|}{ Age class } \\
\hline $19-27$ & Ref & & & Ref & & \\
\hline $28-36$ & $0.186^{* *}$ & 0.050 & $4.9 \%$ & $0.275^{\star *}$ & 0.018 & $6.6 \%$ \\
\hline $37-45$ & $0.345^{\star *}$ & 0.000 & $9.2 \%$ & $0.405^{\star *}$ & 0.000 & $9.7 \%$ \\
\hline $46-55$ & $0.576^{* *}$ & 0.000 & $15.8 \%$ & $0.710^{* *}$ & 0.000 & $18.1 \%$ \\
\hline \multicolumn{7}{|l|}{ Highest education achieved } \\
\hline No certificate & Ref & & & Ref & & \\
\hline Primary education & $0.317^{* *}$ & 0.023 & $9.0 \%$ & 0.022 & 0.904 & $0.5 \%$ \\
\hline Secondary education (general) & -0.123 & 0.332 & $-3.0 \%$ & -0.076 & 0.629 & $-1.6 \%$ \\
\hline Secondary education (profes.) & $-0.199^{* *}$ & 0.030 & $-4.8 \%$ & -0.116 & 0.291 & $-2.6 \%$ \\
\hline O-level. professional & $-0.273^{\star *}$ & 0.021 & $-6.2 \%$ & -0.082 & 0.543 & $-1.8 \%$ \\
\hline O-level. general & -0.103 & 0.360 & $-2.5 \%$ & -0.221 & 0.169 & $-4.5 \%$ \\
\hline 2 years of college education & $-0.326^{* *}$ & 0.003 & $-7.4 \%$ & $-0.405^{\star *}$ & 0.004 & $-7.7 \%$ \\
\hline At least 3 years of college education & $-0.195^{\star *}$ & 0.050 & $-4.7 \%$ & $-0.430^{* *}$ & 0.001 & $-8.3 \%$ \\
\hline \multicolumn{7}{|l|}{ Childhood } \\
\hline Foreign mother & 0.037 & 0.773 & $0.9 \%$ & -0.148 & 0.333 & $-3.2 \%$ \\
\hline Foreign father & 0.105 & 0.392 & $2.7 \%$ & 0.078 & 0.606 & $1.8 \%$ \\
\hline Born in France & 0.131 & 0.245 & $3.2 \%$ & 0.113 & 0.398 & $2.4 \%$ \\
\hline Brought up by the mother & $-0.254^{*}$ & 0.061 & $-7.0 \%$ & 0.151 & 0.418 & $3.2 \%$ \\
\hline Brought up by the father & 0.034 & 0.719 & $0.8 \%$ & -0.084 & 0.484 & $-1.9 \%$ \\
\hline Parents had serious health problems & $0.298^{* *}$ & 0.000 & $8.2 \%$ & $0.198^{* *}$ & 0.039 & $4.7 \%$ \\
\hline Separated from family & $0.220^{* *}$ & 0.010 & $5.9 \%$ & 0.039 & 0.719 & $0.9 \%$ \\
\hline \multicolumn{7}{|l|}{ Alcohol consumption } \\
\hline None & Ref & & & Ref & & \\
\hline Missing & 0.089 & 0.565 & $2.3 \%$ & 0.002 & 0.994 & $0.0 \%$ \\
\hline Without risk & $-0.113^{*}$ & 0.090 & $-2.8 \%$ & -0.044 & 0.682 & $-1.0 \%$ \\
\hline At risk. casual & $-0.192^{\star *}$ & 0.048 & $-4.5 \%$ & -0.171 & 0.123 & $-3.7 \%$ \\
\hline At risk. chronic & 0.138 & 0.517 & $3.7 \%$ & -0.230 & 0.146 & $-4.7 \%$ \\
\hline \multicolumn{7}{|l|}{ Tobacco consumption } \\
\hline None & Ref & & & Ref & & \\
\hline Missing & -0.234 & 0.154 & $-5.5 \%$ & 0.019 & 0.933 & $0.4 \%$ \\
\hline Former daily smoker & $0.192^{\star *}$ & 0.041 & $5.2 \%$ & 0.088 & 0.386 & $2.0 \%$ \\
\hline Casual smoker & 0.031 & 0.813 & $0.8 \%$ & 0.059 & 0.667 & $1.4 \%$ \\
\hline Daily smoker & 0.015 & 0.824 & $0.4 \%$ & 0.096 & 0.238 & $2.2 \%$ \\
\hline \multicolumn{7}{|l|}{ Location } \\
\hline Lives in underprivileged suburbs & -0.032 & 0.759 & $-0.8 \%$ & -0.088 & 0.551 & $-1.9 \%$ \\
\hline \multicolumn{7}{|l|}{ Region : } \\
\hline Ile de France & Ref & & & Ref & & \\
\hline Alsace & -0.038 & 0.803 & $-0.9 \%$ & -0.341 & 0.133 & $-6.5 \%$ \\
\hline Acquitaine & 0.171 & 0.185 & $4.6 \%$ & -0.197 & 0.225 & $-4.0 \%$ \\
\hline Auvergne & 0.009 & 0.964 & $0.2 \%$ & -0.073 & 0.769 & $-1.6 \%$ \\
\hline Basse Normandie & 0.168 & 0.357 & $4.5 \%$ & 0.181 & 0.410 & $4.4 \%$ \\
\hline Bourgogne & 0.097 & 0.541 & $2.5 \%$ & 0.000 & 1.000 & $0.0 \%$ \\
\hline Bretagne & 0.182 & 0.173 & $4.9 \%$ & -0.186 & 0.251 & $-3.8 \%$ \\
\hline Centre & -0.060 & 0.697 & $-1.5 \%$ & -0.226 & 0.206 & $-4.6 \%$ \\
\hline Champagne & -0.056 & 0.750 & $-1.4 \%$ & -0.152 & 0.488 & $-3.2 \%$ \\
\hline Corse & 0.380 & 0.457 & $11.0 \%$ & -0.582 & 0.307 & $-9.6 \%$ \\
\hline Franche Comté & $0.398^{* *}$ & 0.023 & $11.5 \%$ & $-0.475^{\star}$ & 0.065 & $-8.4 \%$ \\
\hline
\end{tabular}




\begin{tabular}{lcccccc} 
Haute Normandie & 0.159 & 0.334 & $4.3 \%$ & -0.065 & 0.767 & $-1.4 \%$ \\
Languedoc Roussillon & $0.240^{*}$ & 0.091 & $6.6 \%$ & $-0.384^{*}$ & 0.064 & $-7.2 \%$ \\
Limousin & -4.117 & 0.953 & $-18.8 \%$ & -0.383 & 0.188 & $-7.1 \%$ \\
Lorraine & $0.347^{* *}$ & 0.012 & $9.9 \%$ & 0.224 & 0.165 & $5.5 \%$ \\
Midi Pyrénées & $0.320^{* *}$ & 0.028 & $9.0 \%$ & 0.075 & 0.668 & $1.7 \%$ \\
Nord Pas de Calais & 0.176 & 0.132 & $4.7 \%$ & -0.174 & 0.230 & $-3.6 \%$ \\
Pays de la Loire & 0.074 & 0.539 & $1.9 \%$ & 0.040 & 0.785 & $0.9 \%$ \\
Picardie & 0.066 & 0.659 & $1.7 \%$ & 0.028 & 0.871 & $0.6 \%$ \\
Poitou Charentes & 0.102 & 0.532 & $2.7 \%$ & 0.180 & 0.346 & $4.4 \%$ \\
Provence Alpes Côte d'Azur & $0.232^{* *}$ & 0.028 & $6.3 \%$ & -0.094 & 0.514 & $-2.0 \%$ \\
Rhône Alpes & -0.099 & 0.388 & $-2.4 \%$ & -0.070 & 0.587 & $-1.5 \%$ \\
\hline \% correct predictions & & $66.5 \%$ & & & $67.0 \%$ & \\
Mac Fadden R-squared & & 0.061 & & & 0.059 & \\
\hline
\end{tabular}


Table 4: Probability of having an accident

Maximum likelihood estimation of the Probit model. ** : significant at the 5\% level; *: significant at the $10 \%$ level

\begin{tabular}{|c|c|c|c|c|c|c|}
\hline & \multicolumn{3}{|c|}{ Women } & \multicolumn{3}{|c|}{ Men } \\
\hline & Parameter & $P$ value & $\begin{array}{c}\text { Average } \\
\text { effect }\end{array}$ & Parameter & $P$ value & $\begin{array}{c}\text { Average } \\
\text { effect }\end{array}$ \\
\hline Intercept & $-1,345$ & 0,000 & & $-1,532$ & 0,000 & \\
\hline \multicolumn{7}{|l|}{ Age class } \\
\hline $19-27$ & Ref & & & Ref & & \\
\hline $28-36$ & 0,142 & 0,169 & $2,9 \%$ & $0,229^{* *}$ & 0,027 & $6,3 \%$ \\
\hline $37-45$ & 0,125 & 0,218 & $2,6 \%$ & $0,344^{* *}$ & 0,000 & $9,5 \%$ \\
\hline $46-55$ & $0,558^{* *}$ & 0,000 & $12,3 \%$ & $0,576^{* *}$ & 0,000 & $16,5 \%$ \\
\hline \multicolumn{7}{|l|}{ Highest education achieved } \\
\hline No certificate & Ref & & & Ref & & \\
\hline Primary education & $-0,325^{*}$ & 0,096 & $-5,5 \%$ & 0,119 & 0,508 & $3,3 \%$ \\
\hline Secondary education (general) & 0,044 & 0,741 & $0,9 \%$ & 0,273 & 0,067 & $7,9 \%$ \\
\hline Secondary education (profes.) & $-0,219^{* *}$ & 0,031 & $-4,1 \%$ & 0,146 & 0,181 & $3,9 \%$ \\
\hline O-level. professional & $-0,398^{* *}$ & 0,004 & $-6,7 \%$ & 0,144 & 0,281 & $4,0 \%$ \\
\hline O-level. general & $-0,334^{* *}$ & 0,013 & $-5,8 \%$ & $0,252^{*}$ & 0,088 & $7,2 \%$ \\
\hline 2 years of college education & $-0,334^{* *}$ & 0,007 & $-5,9 \%$ & 0,091 & 0,482 & $2,5 \%$ \\
\hline At least 3 years of college education & $-0,137$ & 0,211 & $-2,6 \%$ & 0,096 & 0,435 & $2,6 \%$ \\
\hline \multicolumn{7}{|l|}{ Childhood } \\
\hline Foreign mother & 0,205 & 0,167 & $4,4 \%$ & $-0,068$ & 0,631 & $-1,8 \%$ \\
\hline Foreign father & $-0,517^{\star *}$ & 0,001 & $-8,4 \%$ & $-0,068$ & 0,636 & $-1,8 \%$ \\
\hline Born in France & $-0,194$ & 0,131 & $-4,2 \%$ & 0,095 & 0,452 & $2,4 \%$ \\
\hline Brought up by the mother & $-0,237$ & 0,119 & $-5,2 \%$ & 0,090 & 0,582 & $2,3 \%$ \\
\hline Brought up by the father & 0,138 & 0,187 & $2,6 \%$ & $-0,147$ & 0,175 & $-4,0 \%$ \\
\hline Parents had serious health problems & $0,354^{* *}$ & 0,000 & $8,0 \%$ & $0,447^{* *}$ & 0,000 & $13,3 \%$ \\
\hline Separated from family & $0,423^{* *}$ & 0,000 & $9,8 \%$ & 0,139 & 0,151 & $3,8 \%$ \\
\hline \multicolumn{7}{|l|}{ Alcohol consumption } \\
\hline None & Ref & & & Ref & & \\
\hline Missing & 0,097 & 0,625 & $2,0 \%$ & $0,437^{* *}$ & 0,040 & $12,9 \%$ \\
\hline Without risk & 0,115 & 0,153 & $2,3 \%$ & 0,122 & 0,247 & $3,3 \%$ \\
\hline At risk. casual & 0,159 & 0,142 & $3,3 \%$ & 0,028 & 0,794 & $0,7 \%$ \\
\hline At risk. chronic & $-0,029$ & 0,916 & $-0,6 \%$ & $0,385^{* *}$ & 0,005 & $11,4 \%$ \\
\hline \multicolumn{7}{|l|}{ Tobacco consumption } \\
\hline None & Ref & & & Ref & & \\
\hline Missing & 0,213 & 0,290 & $4,6 \%$ & $-0,092$ & 0,655 & $-2,4 \%$ \\
\hline Former daily smoker & $0,189^{*}$ & 0,074 & $4,0 \%$ & 0,035 & 0,707 & $0,9 \%$ \\
\hline Casual smoker & 0,119 & 0,426 & $2,5 \%$ & $-0,387^{* *}$ & 0,012 & $-8,8 \%$ \\
\hline Daily smoker & $0,135^{*}$ & 0,083 & $2,8 \%$ & 0,071 & 0,333 & $1,9 \%$ \\
\hline \multicolumn{7}{|l|}{ Location } \\
\hline Lives in underprivileged suburbs & $0,216^{*}$ & 0,053 & $4,7 \%$ & 0,066 & 0,619 & $1,8 \%$ \\
\hline \multicolumn{7}{|l|}{ Region : } \\
\hline Ile de France & Ref & & & Ref & & \\
\hline Alsace & 0,060 & 0,733 & $1,2 \%$ & 0,218 & 0,202 & $6,2 \%$ \\
\hline Acquitaine & $0,303^{\star *}$ & 0,034 & $6,8 \%$ & $-0,063$ & 0,657 & $-1,6 \%$ \\
\hline Auvergne & $0,683^{* *}$ & 0,000 & $18,0 \%$ & 0,179 & 0,395 & $5,0 \%$ \\
\hline Basse Normandie & $0,399^{* *}$ & 0,032 & $9,5 \%$ & $0,647^{* *}$ & 0,000 & $20,6 \%$ \\
\hline Bourgogne & 0,081 & 0,671 & $1,7 \%$ & 0,098 & 0,597 & $2,7 \%$ \\
\hline Bretagne & 0,233 & 0,114 & $5,1 \%$ & $-0,081$ & 0,572 & $-2,1 \%$ \\
\hline Centre & 0,111 & 0,520 & $2,3 \%$ & $-0,521^{* *}$ & 0,008 & $-11,2 \%$ \\
\hline Champagne & 0,032 & 0,871 & $0,6 \%$ & $0,292^{*}$ & 0,098 & $8,5 \%$ \\
\hline Corse & $-3,567$ & 0,963 & $-13,7 \%$ & 0,040 & 0,930 & $1,1 \%$ \\
\hline Franche Comté & $0,572^{\star *}$ & 0,003 & $14,5 \%$ & $-0,051$ & 0,795 & $-1,3 \%$ \\
\hline
\end{tabular}




\begin{tabular}{|c|c|c|c|c|c|c|}
\hline Haute Normandie & 0,135 & 0,476 & $2,9 \%$ & $-0,189$ & 0,380 & $-4,6 \%$ \\
\hline Languedoc Roussillon & 0,013 & 0,942 & $0,3 \%$ & $-0,175$ & 0,307 & $-4,3 \%$ \\
\hline Limousin & $0,632^{* *}$ & 0,008 & $16,4 \%$ & 0,133 & 0,521 & $3,7 \%$ \\
\hline Lorraine & $0,624^{* *}$ & 0,000 & $16,0 \%$ & $-0,158$ & 0,373 & $-3,9 \%$ \\
\hline Midi Pyrénées & 0,055 & 0,776 & $1,1 \%$ & $-0,074$ & 0,663 & $-1,9 \%$ \\
\hline Nord Pas de Calais & $-0,039$ & 0,790 & $-0,8 \%$ & $-0,029$ & 0,823 & $-0,7 \%$ \\
\hline Pays de la Loire & $-0,011$ & 0,941 & $-0,2 \%$ & $-0,254^{*}$ & 0,088 & $-6,1 \%$ \\
\hline Picardie & $-0,210$ & 0,303 & $-3,8 \%$ & $-0,345^{*}$ & 0,071 & $-8,0 \%$ \\
\hline Poitou Charentes & $0,341^{* *}$ & 0,046 & $7,9 \%$ & $-0,010$ & 0,957 & $-0,3 \%$ \\
\hline Provence Alpes Côte d'Azur & 0,012 & 0,932 & $0,2 \%$ & 0,003 & 0,981 & $0,1 \%$ \\
\hline Rhône Alpes & $0,364^{* *}$ & 0,002 & $8,3 \%$ & 0,110 & 0,330 & $3,0 \%$ \\
\hline$\%$ correct predictions & & $70,9 \%$ & & & $67,6 \%$ & \\
\hline Mac Fadden R-squared & & 0,093 & & & 0,073 & \\
\hline
\end{tabular}


Table 5: Effects of chronic illnesses on the performance variables

**: significant at the 5\% level; *: significant at the $10 \%$ level. The chronic illness probabilities are derived from Table 3.

\begin{tabular}{|c|c|c|c|c|c|c|c|c|c|c|c|c|c|c|}
\hline \multirow{3}{*}{ Variable } & \multicolumn{7}{|c|}{ Women } & \multicolumn{7}{|c|}{ Men } \\
\hline & \multicolumn{2}{|c|}{$\begin{array}{c}\text { Average treatment } \\
\text { effect (ATE) }\end{array}$} & \multicolumn{2}{|c|}{$\begin{array}{c}\text { Average treatment } \\
\text { effect on the not } \\
\text { treated (ATN) }\end{array}$} & \multicolumn{2}{|c|}{$\begin{array}{l}\text { Average treatment } \\
\text { effect on the treated } \\
\text { (ATT) }\end{array}$} & \multirow{2}{*}{$\begin{array}{l}\% \text { Obs in } \\
\text { common } \\
\text { support }\end{array}$} & \multicolumn{2}{|c|}{$\begin{array}{c}\text { Average treatment } \\
\text { effect (ATE) }\end{array}$} & \multicolumn{2}{|c|}{$\begin{array}{l}\text { Average treatment } \\
\text { effect on the not } \\
\text { treated (ATN) }\end{array}$} & \multicolumn{2}{|c|}{$\begin{array}{l}\text { Average treatment } \\
\text { effect on the treated } \\
\text { (ATT) }\end{array}$} & \multirow{2}{*}{$\begin{array}{l}\% \text { Obs in } \\
\text { common } \\
\text { support }\end{array}$} \\
\hline & Effect & $P$ value & Effect & $P$ value & Effect & $P$ value & & Effect & $P$ value & Effect & $P$ value & Effect & $P$ value & \\
\hline Has been working last week & -0.026 & 0.310 & -0.021 & 0.440 & $-0.047^{* *}$ & 0.033 & $94.9 \%$ & -0.024 & 0.493 & -0.017 & 0.669 & $-0.066^{* *}$ & 0.005 & $93.8 \%$ \\
\hline Number of hours worked last week (if $>0$ ) & -0.865 & 0.436 & -0.575 & 0.636 & $-2.225^{\star \star}$ & 0.003 & $93.2 \%$ & -1.263 & 0.457 & -1.151 & 0.541 & $-1.907^{\star *}$ & 0.027 & $95.9 \%$ \\
\hline Subjective satisfaction degree of the career : missing & $-0.022^{* *}$ & 0.024 & $-0.024^{* *}$ & 0.017 & -0.012 & 0.189 & $94.9 \%$ & -0.007 & 0.512 & -0.008 & 0.491 & -0.002 & 0.764 & $93.8 \%$ \\
\hline Subjective satisfaction degree of the career (if $>0$ ) & $-0.402^{* *}$ & 0.031 & $-0.397^{*}$ & 0.052 & $-0.421^{* *}$ & 0.002 & $95.8 \%$ & $-0.538^{* *}$ & 0.023 & $-0.530^{* *}$ & 0.042 & $-0.579^{* *}$ & 0.000 & $93.8 \%$ \\
\hline Minimum assistance revenue last month & $0.018^{*}$ & 0.075 & $0.019^{*}$ & 0.074 & 0.014 & 0.153 & $94.9 \%$ & 0.002 & 0.763 & 0.001 & 0.894 & 0.008 & 0.364 & $93.8 \%$ \\
\hline Household monthly revenue : missing & 0.004 & 0.704 & 0.005 & 0.649 & -0.001 & 0.923 & $94.9 \%$ & -0.015 & 0.134 & -0.014 & 0.187 & $-0.022^{* *}$ & 0.017 & $93.8 \%$ \\
\hline Less than 1200 Euros & $0.050^{\star *}$ & 0.005 & $0.048^{\star *}$ & 0.010 & $0.058^{* *}$ & 0.001 & $94.9 \%$ & $0.048^{* *}$ & 0.046 & $0.047^{*}$ & 0.061 & $0.048^{* *}$ & 0.018 & $93.8 \%$ \\
\hline $1200-2500$ & -0.011 & 0.653 & -0.010 & 0.689 & -0.014 & 0.541 & $94.9 \%$ & 0.034 & 0.325 & 0.036 & 0.320 & 0.020 & 0.494 & $93.8 \%$ \\
\hline $2500-4000$ & -0.007 & 0.734 & -0.008 & 0.730 & -0.005 & 0.796 & $94.9 \%$ & -0.012 & 0.671 & -0.013 & 0.666 & -0.008 & 0.767 & $93.8 \%$ \\
\hline More than 4000 Euros & $-0.031^{* *}$ & 0.034 & $-0.030^{* *}$ & 0.046 & $-0.033^{\star *}$ & 0.015 & $94.9 \%$ & -0.026 & 0.218 & -0.024 & 0.291 & $-0.038^{* *}$ & 0.024 & $93.8 \%$ \\
\hline
\end{tabular}


Table 6: Effects of accidents on the performance variables

**: significant at the 5\% level; *: significant at the 10\% level. The accident probabilities are derived from Table 4.

\begin{tabular}{|c|c|c|c|c|c|c|c|c|c|c|c|c|c|c|}
\hline \multirow{3}{*}{ Variable } & \multicolumn{7}{|c|}{ Women } & \multicolumn{7}{|c|}{ Men } \\
\hline & \multicolumn{2}{|c|}{$\begin{array}{l}\text { Average treatment } \\
\text { effect (ATE) }\end{array}$} & \multicolumn{2}{|c|}{$\begin{array}{l}\text { Average treatment } \\
\text { effect on the not } \\
\text { treated (ATN) }\end{array}$} & \multicolumn{2}{|c|}{$\begin{array}{l}\text { Average treatment } \\
\text { effect on the treated } \\
\text { (ATT) }\end{array}$} & \multirow{2}{*}{$\begin{array}{c}\% \text { Obs in } \\
\text { common } \\
\text { support }\end{array}$} & \multicolumn{2}{|c|}{$\begin{array}{c}\text { Average treatment } \\
\text { effect (ATE) }\end{array}$} & \multicolumn{2}{|c|}{$\begin{array}{c}\text { Average treatment } \\
\text { effect on the not } \\
\text { treated (ATN) }\end{array}$} & \multicolumn{2}{|c|}{$\begin{array}{l}\text { Average treatment } \\
\text { effect on the treated } \\
\text { (ATT) }\end{array}$} & \multirow{2}{*}{$\begin{array}{l}\text { \% Obs ir } \\
\text { common } \\
\text { support }\end{array}$} \\
\hline & Effect & $P$ value & Effect & $P$ value & Effect & $P$ value & & Effect & $P$ value & Effect & $P$ value & Effect & $P$ value & \\
\hline Has been working last week & $-0,006$ & 0,889 & 0,003 & 0,947 & $-0,060^{* *}$ & 0,027 & $93.4 \%$ & $-0,035$ & 0,159 & $-0,029$ & 0,288 & $-0,060^{\star \star}$ & 0,002 & $93.6 \%$ \\
\hline Number of hours worked last week (if $>0$ ) & 0,589 & 0,776 & 0,810 & 0,721 & $-0,919$ & 0,390 & $90.1 \%$ & $-0,787$ & 0,465 & $-0,702$ & 0,564 & $-1,113$ & 0,137 & $94.8 \%$ \\
\hline Subjective satisfaction degree of the career : missing & $-0,049^{* *}$ & 0,000 & $-0,051^{* *}$ & 0,000 & $-0,036^{* *}$ & 0,001 & $93.4 \%$ & $-0,010$ & 0,191 & $-0,011$ & 0,190 & $-0,006$ & 0,225 & $93.6 \%$ \\
\hline Subjective satisfaction degree of the career (if $>0$ ) & $-0,018$ & 0,958 & 0,037 & 0,921 & $-0,359^{*}$ & 0,059 & $92.1 \%$ & $-0,506^{* *}$ & 0,010 & $-0,435^{* *}$ & 0,047 & $-0,784^{* *}$ & 0,000 & $93.2 \%$ \\
\hline Minimum assistance revenue last month & $0,018^{*}$ & 0,055 & 0,013 & 0,202 & $0,054^{* *}$ & 0,000 & $93.4 \%$ & 0,011 & 0,249 & 0,013 & 0,224 & 0,004 & 0,605 & $93.6 \%$ \\
\hline Household monthly revenue : missing & $-0,037^{* *}$ & 0,000 & $-0,037^{* *}$ & 0,000 & $-0,035^{\star *}$ & 0,000 & $93.4 \%$ & $-0,012$ & 0,136 & $-0,013^{*}$ & 0,094 & $-0,006$ & 0,542 & $93.6 \%$ \\
\hline Less than 1200 Euros & $0,093^{* *}$ & 0,001 & $0,093^{* *}$ & 0,001 & $0,094^{* *}$ & 0,000 & $93.4 \%$ & $0,037^{* *}$ & 0,037 & $0,036^{*}$ & 0,052 & $0,039^{* *}$ & 0,027 & $93.6 \%$ \\
\hline $1200-2500$ & $-0,001$ & 0,980 & $-0,007$ & 0,842 & 0,036 & 0,195 & $93.4 \%$ & $-0,013$ & 0,635 & $-0,007$ & 0,813 & $-0,038$ & 0,145 & $93.6 \%$ \\
\hline $2500-4000$ & $-0,038$ & 0,205 & $-0,036$ & 0,257 & $-0,049^{* *}$ & 0,037 & $93.4 \%$ & 0,009 & 0,728 & 0,009 & 0,734 & 0,008 & 0,752 & $93.6 \%$ \\
\hline More than 4000 Euros & 0,017 & 0,512 & 0,024 & 0,386 & $-0,028^{*}$ & 0,100 & $93.4 \%$ & $-0,044^{* *}$ & 0,004 & $-0,042^{* *}$ & 0,008 & $-0,053^{* *}$ & 0,002 & $93.6 \%$ \\
\hline
\end{tabular}




\section{APPENDIX}

Table A-1: Naïve estimators of the effects of chronic illnesses

(potentially biased, given for comparison with the evaluation estimators in Table 5)

The OLS regressions include all the variables presented in the Table 3 Probit model as controls. **: significant at the $5 \%$ level; *: significant at the $10 \%$ level.

\begin{tabular}{|c|c|c|c|c|c|c|c|c|c|c|c|c|c|c|}
\hline \multirow{3}{*}{ Variable } & \multicolumn{7}{|c|}{ Women } & \multicolumn{7}{|c|}{ Men } \\
\hline & \multicolumn{2}{|c|}{$\begin{array}{c}\text { Difference of the } \\
\text { means }\end{array}$} & \multicolumn{2}{|c|}{$\begin{array}{l}\text { OLS with chronic } \\
\text { illness dummy }\end{array}$} & \multicolumn{2}{|c|}{$\begin{array}{l}\text { OLS with chronic } \\
\text { illness dummy and } \\
\text { cross products }\end{array}$} & \multirow[t]{2}{*}{ Obs. } & \multicolumn{2}{|c|}{$\begin{array}{c}\text { Difference of the } \\
\text { means }\end{array}$} & \multicolumn{2}{|c|}{$\begin{array}{l}\text { OLS with chronic } \\
\text { illness dummy }\end{array}$} & \multicolumn{2}{|c|}{$\begin{array}{l}\text { OLS with chronic } \\
\text { illness dummy and } \\
\text { cross products }\end{array}$} & \multirow[t]{2}{*}{ Obs } \\
\hline & Effect & $P$ value & Effect & $P$ value & Effect & $P$ value & & Effect & $P$ value & Effect & $P$ value & Effect & $P$ value & \\
\hline Has been working last week & $-0.057^{* *}$ & 0.006 & $-0.044^{* *}$ & 0.028 & -0.02 & 0.314 & 3358 & $-0.043^{*}$ & 0.055 & $-0.065^{\star *}$ & 0.001 & $-0.052^{* \star}$ & 0.016 & 2451 \\
\hline Number of hours worked last week (if >0) & $-1.868^{* *}$ & 0.003 & $-1.775^{\star *}$ & 0.005 & $-1.180^{*}$ & 0.060 & 2358 & $-2.026^{* *}$ & 0.002 & $-2.081^{* *}$ & 0.001 & $-1.633^{* *}$ & 0.014 & 2028 \\
\hline Subjective satisfaction degree of the career : missing & -0.016 & 0.103 & -0.012 & 0.171 & -0.02 & 0.029 & 3358 & $-0.018^{* *}$ & 0.025 & -0.006 & 0.461 & -0.007 & 0.478 & 2451 \\
\hline Subjective satisfaction degree of the career (if $>0$ ) & $-0.480^{* *}$ & 0.000 & $-0.382^{* *}$ & 0.001 & $-0.386^{* *}$ & 0.001 & 3142 & $-0.585^{* *}$ & 0.000 & $-0.615^{\star \star}$ & 0.000 & $-0.642^{* *}$ & 0.000 & 2368 \\
\hline Minimum assistance revenue last month & $0.024^{* *}$ & 0.013 & 0.015 & 0.110 & $0.016^{*}$ & 0.084 & 3358 & 0.015 & 0.104 & 0.012 & 0.176 & 0.004 & 0.601 & 2451 \\
\hline Household monthly revenue : missing & 0.001 & 0.896 & 0.001 & 0.956 & 0.005 & 0.643 & 3358 & $-0.022^{* *}$ & 0.008 & $-0.020^{\star *}$ & 0.018 & $-0.017^{*}$ & 0.069 & 2451 \\
\hline Less than 1200 Euros & $0.072^{* *}$ & 0.000 & $0.057^{\star *}$ & 0.001 & $0.047^{* *}$ & 0.006 & 3358 & $0.055^{\star *}$ & 0.007 & $0.057^{* *}$ & 0.004 & $0.049^{\star *}$ & 0.019 & 2451 \\
\hline $1200-2500$ & -0.016 & 0.450 & -0.015 & 0.480 & -0.012 & 0.585 & 3358 & 0.021 & 0.456 & 0.013 & 0.631 & 0.009 & 0.734 & 2451 \\
\hline $2500-4000$ & -0.024 & 0.212 & -0.009 & 0.660 & -0.007 & 0.737 & 3358 & -0.010 & 0.696 & -0.013 & 0.600 & -0.021 & 0.417 & 2451 \\
\hline More than 4000 Euros & $-0.033^{* *}$ & 0.014 & $-0.034^{* *}$ & 0.010 & $-0.032^{* *}$ & 0.019 & 3358 & $-0.044^{* *}$ & 0.011 & $-0.036^{\star *}$ & 0.029 & -0.019 & 0.324 & 2451 \\
\hline
\end{tabular}


Table A-2: Naive estimators of the effects of accidents

(potentially biased. for comparison with the evaluation estimators in Table 6)

The OLS regressions include all the variables presented in the Table 4 Probit model as controls. ** : significant at the $5 \%$ level; * $:$ significant at the $10 \%$ level.

$$
\text { Women }
$$

\begin{tabular}{|c|c|c|c|c|c|c|c|c|c|c|c|c|c|c|}
\hline \multirow{3}{*}{ Variable } & \multicolumn{6}{|c|}{ Women } & \multirow{3}{*}{ Obs. } & \multicolumn{7}{|c|}{ WretI } \\
\hline & \multicolumn{2}{|c|}{$\begin{array}{l}\text { Difference of the } \\
\text { means }\end{array}$} & \multicolumn{2}{|c|}{$\begin{array}{c}\text { OLS with accident } \\
\text { dummy }\end{array}$} & \multicolumn{2}{|c|}{$\begin{array}{c}\text { OLS with accident } \\
\text { dummy and cross } \\
\text { products }\end{array}$} & & \multicolumn{2}{|c|}{$\begin{array}{c}\text { Difference of the } \\
\text { means }\end{array}$} & \multicolumn{2}{|c|}{$\begin{array}{c}\text { OLS with accident } \\
\text { dummy }\end{array}$} & \multicolumn{2}{|c|}{$\begin{array}{c}\text { OLS with accident } \\
\text { dummy and cross } \\
\text { products }\end{array}$} & \multirow[t]{2}{*}{ Obs. } \\
\hline & Effect & $P$ value & Effect & $P$ value & Effect & $P$ value & & Effect & $P$ value & Effect & $P$ value & Effect & $P$ value & \\
\hline Has been working last week & $-0,053^{* *}$ & 0,029 & $-0,054^{* *}$ & 0,021 & $-0,037$ & 0,152 & 3163 & $-0,005$ & 0,781 & $-0,037^{* *}$ & 0,027 & $-0,029$ & 0,115 & 2611 \\
\hline Number of hours worked last week (if $>0$ ) & $-1,519^{* *}$ & 0,038 & $-1,260^{*}$ & 0,071 & $-0,603$ & 0,387 & 2232 & $-0,969^{*}$ & 0,089 & $-1,394^{* *}$ & 0,016 & $-1,285^{* *}$ & 0,028 & 2175 \\
\hline Subjective satisfaction degree of the career : missing & $-0,037^{* *}$ & 0,000 & $-0,038^{* *}$ & 0,000 & $-0,047^{* *}$ & 0,000 & 3163 & $-0,024^{* *}$ & 0,000 & $-0,002$ & 0,678 & $-0,002$ & 0,853 & 2611 \\
\hline Subjective satisfaction degree of the career (if $>0$ ) & $-0,494^{* *}$ & 0,000 & $-0,339^{* *}$ & 0,009 & $-0,198$ & 0,163 & 2966 & $-0,369^{* *}$ & 0,001 & $-0,422^{* *}$ & 0,000 & $-0,472^{* *}$ & 0,000 & 2528 \\
\hline Minimum assistance revenue last month & $0,053^{* *}$ & 0,000 & $0,038^{* *}$ & 0,002 & $0,025^{\star *}$ & 0,027 & 3163 & 0,004 & 0,547 & 0,006 & 0,360 & 0,010 & 0,262 & 2611 \\
\hline Household monthly revenue : missing & $-0,036^{* *}$ & 0,000 & $-0,035^{* *}$ & 0,000 & $-0,036^{* *}$ & 0,000 & 3163 & $-0,008$ & 0,331 & $-0,006$ & 0,509 & $-0,010$ & 0,294 & 2611 \\
\hline Less than 1200 Euros & $0,107^{* *}$ & 0,000 & $0,085^{* *}$ & 0,000 & $0,090^{* *}$ & 0,000 & 3163 & $0,034^{* *}$ & 0,044 & $0,045^{\star *}$ & 0,004 & $0,040^{\star *}$ & 0,019 & 2611 \\
\hline $1200-2500$ & 0,014 & 0,585 & 0,029 & 0,267 & 0,017 & 0,549 & 3163 & $-0,009$ & 0,693 & $-0,005$ & 0,845 & 0,016 & 0,522 & 2611 \\
\hline $2500-4000$ & $-0,058^{* *}$ & 0,008 & $-0,051^{* *}$ & 0,019 & $-0,069^{\star *}$ & 0,004 & 3163 & 0,008 & 0,720 & 0,002 & 0,941 & $-0,015$ & 0,508 & 2611 \\
\hline More than 4000 Euros & $-0,027^{*}$ & 0,085 & $-0,027^{\star}$ & 0,089 & $-0,003$ & 0,881 & 3163 & $-0,024$ & 0,136 & $-0,037^{* *}$ & 0,015 & $-0,032^{* *}$ & 0,040 & 2611 \\
\hline
\end{tabular}

